\title{
WOMEN AND ECONOMICS
}





\section{Women and Economics}

A Study of the Economic Relation

Between Men and Women as a

Factor in Social Evolution

\section{Charlotte Perkins Gilman}

With a New Introduction

by Michael Kimmel and Amy Aronson

UNIVERSITY OF CALIFORNIA PRESS

Berkeley - Los Angeles - London 
University of California Press

Berkeley and Los Angeles, California

University of California Press, Ltd.

London, England

First University of California Press Paperback, 1998

Introduction $\odot 1998$ by

Michael Kimmel and Amy Aronson

Library of Congress Cataloging-in-Publication Data

Gilman, Charlotte Perkins, 1860-1935.

Women and economics : a study of the economic relation between men and women as a factor in social evolution / Charlotte Perkins Gilman ; with a new introduction by Michael Kimmel and Amy Aronson.

p. $\mathrm{cm}$.

Originally published: Boston : Small, Maynard \& Co., 1898. Includes index.

ISBN 0-520-20998-2 (pbk. : alk. paper)

I. Women-Economic conditions. I. Title.

HQ1381.G66 1998

305.42-dc21

Printed in the United States of America

$\begin{array}{lllllllll}9 & 8 & 7 & 6 & 5 & 4 & 3 & 2 & 1\end{array}$

The paper used in this publication is both acid-free and totally chlorine-free (TCF). It meets the minimum requirements of American Standard for Information Sciences-Permanence of Paper for Printed Library Materials, ANSI Z39.48-1984. (-) 